\title{
Insights from a Recruiter
}

\section{RUSSELL REYNOLDS' DEBRA BROWN SHARES ADVICE FOR INVESTMENT PROFESSIONALS}

By Julia VanDeren

When is the right time to reach out to a recruiter?

To get an answer, I talked with Debra Brown, a New York-based recruiter for Russell Reynolds Associates' asset and wealth management practice. During our discussion this past June, Brown offered career management advice tailored specifically for investment professionals. Based on her experience completing searches for CEOs, chief investment officers (CIOs), portfolio managers, and senior sector analysts, among other positions, she provided the following insights regarding when and how to recruit for senior- and executive-level positions within the finance industry.

\section{GETTING TARGETED BY RECRUITERS}

Companies engage recruiters to find candidates they cannot easily find themselves. For better or worse, this leads recruiters to look for professionals who are content in their jobs and successful at other companies. After all, individuals who are actively promoting themselves for job openings or otherwise show obvious interest in new opportunities would probably pop up on the radar of the hiring company without the help of a search firm. Still, recruiters are interested in building their networks of talented professionals, so they aren't inclined to ignore proactive attempts to connect. They recognize that eventually you may be exactly the person they are looking for.

\section{INCLUDING RECRUITERS IN YOUR NETWORK}

As a professional, when does it make sense to reach out to a recruiter? That varies, depending on the specific recruiter's perspective, but Brown estimates that 10 years of experience is probably the minimum point at which conversations with an executive search professional will begin to have an immediate impact for either side. She also notes that, for the economics to be mutually beneficial, the job roles a potential recruit would be coming from and going to should be compensated at or above the threshold of US $\$ 300,000$.

Of course, reaching out to recruiters for immediate job opportunities is not the same thing as incorporating recruiters into your professional network. That's something you should do long before you need their help.

\section{TIME TO HIRE VS. TIME TO GET HIRED}

On the employer side of the equation, for the types of positions that Brown recruits, it currently takes an average of three to five months to complete a search and hire someone into a role. Brown says this timeframe hasn't changed much over the past several years. What has changed, though, is that recruiters are identifying potential talent earlier, while the process of interviewing and making, negotiating, and accepting an offer now takes up a greater amount of that time. If you are tapped by a recruiter, it's worth noting that you may be in for a long hiring process, even if you are on a very short list of potential hires.

For the job seeker, Brown reports that, on average, she's seeing the search take 6-12 months (and potentially longer) for senior professionals to get hired during an active job search. Obviously, this duration has implications for someone planning to change jobs. For example, while you need to keep assessing whether your search strategy is really working for you, there is no need to panic if you haven't landed a new job within a few weeks of launching your search.

\section{CAREER PATHS}

In terms of what skills and talents are in demand in the finance sector, one trend Brown has noticed is that greater value is being placed on experience in multiasset class investing and holistic, global understanding of risk. Although a typical path might tend toward continued specialization, Brown recommends that you be on the lookout for opportunities outside of your asset class silo. In other words, specialize enough to legitimately claim a particular expertise, but consider taking steps to gain experience working with other asset classes as well.

Julia VanDeren is the career services representative at CFA Institute. This article was originally published on the Enterprising Investor blog (blogs.cfainstitute.org/investor).

\section{Misconceptions about Shadow Banking in China}

CFA Institute recently held a media roundtable between parties in Beijing and Hong Kong, where Alan Lok, CFA, director of capital markets policy at CFA Institute, discussed the development of China's shadow banking sector and what it means for investors and the larger financial system.

The event, which led to more than 30 instances of coverage in local and regional media, examined the lack of investor awareness of the risks posed by shadow banking in China and the role CFA Institute can play in investor education. As Lok explained, however, when viewed within the global financial system as a whole, these potential risks are largely overblown. Despite headline-grabbing, double-digit annual growth rates, the amount of shadow banking assets in China (just 4\%) remains relatively low from a global perspective when compared with the United States (33\%) and the wider euro area (34\%), according to estimates reported by the Financial Stability Board (FSB) in 2013. (The FSB report defines a "euro area" that includes 20 non-euro area jurisdictions.) Commenting on the recent stock market volatility in China, Lok says, "The huge capital supplied by shadow banks may be one of the reasons for the market volatility, but it is not the only reason."

The media briefing follows the global release of the CFA Institute report Shadow Banking: Policy Frameworks and Investor Perspectives on Markets-Based Finance and a CFA Institute Annual Conference session on shadow banking. 